Bangladesh J. Plant Taxon. 16(1): 73-82, 2009 (June)

(C) 2009 Bangladesh Association of Plant Taxonomists

\title{
COMPARATIVE MORPHOLOGY, ANATOMY AND PALYNOLOGY OF TWO SALVIA L. SPECIES (LAMIACEAE) AND THEIR TAXONOMIC IMPLICATIONS
}

\author{
Ahmet Kahraman ${ }^{1,2}$, Ferhat Celep ${ }^{2}$ and Musa Dogan \\ Department of Biological Sciences, Middle East Technical University, Ankara, Turkey. \\ Keywords: Morphology; Anatomy; Palynology; Salvia.
}

\begin{abstract}
Morphological, anatomical and palynological characteristics of Salvia glutinosa L. and S. staminea Montbret \& Aucher ex Bentham and their taxonomic importance are presented. Their expanded description and phenology are also given. The features of stems, leaves, calyces, corolla and nutlets have been found to be significant to distinguish the species. Mesophyll structure, distribution of stomata on upper epidermis, size of stomata on lower epidermis, shape of vascular structure in midrib, and number of vascular bundles and presence of sclerenchymatic fibers in petiole are diagnostic characters. Moreover, pollen size and exine ornamentation are important in separating these two species.
\end{abstract}

\section{Introduction}

Salvia L. (Lamiaceae) is represented by about 1000 species displaying a remarkable diversity in growth forms, secondary compounds, floral morphology, and pollination biology. The genus is distributed extensively in three regions of the world: Central and South America (500 spp.), western Asia (200 spp.) and eastern Asia (100 spp.) (Walker and Sytsma, 2007). Turkey is a major diversity center for Salvia in Asia (Hamzaoglu et al., 2005). The first revision of Salvia L. in Turkey was made by Hedge (1982), who recognized 86 species, one hybrid and one doubtful species. Since then, six more new species and three new records have been described from Turkey. The genus Salvia has been subject to a number of studies mainly based on morphological (Hedge, 1982), anatomical (Metcalfe and Chalk, 1965; Kaya et al., 2007; Kahraman et al., 2009a, b) and palynological (Cantino et al., 1992) information.

Boissier (1875) recorded 75 species of Salvia from Turkey and placed them under seven sections using Bentham's (1833) sectional delimitation. Boissier (1875) placed Salvia glutinosa L. in the section Drymosphace and S. staminea Montbret \& Aucher ex Bentham in the section Plethiosphace. Since 2005, as a part of a revision of the genus Salvia in Turkey, the present authors have carried out extensive field studies and collected a large number of specimens. Although S. glutinosa and S. staminea belong to different sections, some morphological characteristics of these two species overlap such as stem indumentum, leaf size, petiole length, inflorescence length, number of verticillasters, stamen type, and bract shape and size. Anatomical and palynological

\footnotetext{
${ }^{1}$ Corresponding author. E-mail: ahmetk@metu.edu.tr

${ }^{2}$ Department of Biology, Ataturk University, 25240, Erzurum, Turkey.
} 
structures of these species, however, have not been studied before. The present study thus aims to clarify taxonomic importance of anatomical and palynological characters in addition to morphological ones for distinguishing these two species and their sections.

\section{Materials and Methods}

Plant specimens were collected from different localities in Turkey. The specimens have been stored in Ankara University Herbarium (ANK).

Anatomical studies were carried out on specimens kept in $70 \%$ alcohol. The paraffin method was used for the transverse sections of stem, leaf and petiole. The specimens were embedded in paraffin and then sectioned with a Leica RM2125RT rotary microtome. All sections were stained with safranin and fast green and then mounted with canada balsam. Measurements and photographs were taken using a Leica DM1000 binocular light microscope with a Leica DFC280 camera.

For palynological investigations, pollen materials were obtained from herbarium specimens. The pollen slides were prepared according to Wodehouse (1935) technique. For light microscope (LM) studies, measurements and observations were made using the Leica DM1000 binocular light microscope with the Leica DFC280 camera. The polar length, equatorial length, colpus length, exine and intine thickness for 30 pollen grains were measured under the light microscope (X 1000) and polar axis/equatorial axis (P/E) ratios were calculated. For scanning electron microscopy (SEM), the pollen grains were observed and photographed with a JEOL-6060 scanning electron microscope to determine their exine ornamentation. Pollen terminology of Punt et al. (2007) has been used.

\section{Results and Discussion}

\section{Morphological characteristics}

S. glutinosa L., Sp. PI. 26 (1753). Ic: Fl. RPR 8: t. 39 f. 1 (1961); Huxley \& Taylor, Fls. Greece t. 237 (1977).

Stems up to $1 \mathrm{~m}$ tall, erect, branched above. The stem indumentum sparsely eglandular and glandular pilose to villous. Leaves simple, 4-20 $\times 3-12 \mathrm{~cm}$, ovate-triangular, sagittate-hastate, serrate. The leaf indumentum subglabrous to sparsely pilose on veins, with sessile glands. Petiole $4-11 \mathrm{~cm}$ long. Inflorescence $15-45 \mathrm{~cm}$ long, densely glandular pilose to villous. Verticillasters 4-6-flowered, distant. Bracts 6-14 $\times 4-8 \mathrm{~mm}$, ovate. Bracteoles present. Pedicels up to $5 \mathrm{~mm}$ long, erecto-patent, elongating in fruit. Calyx 10-14 mm long, up to $20 \mathrm{~mm}$ in fruit, tubular to campanulate, upper lip 1-dentate, almost straight. Calyx indumentum densely glandular-villous. Corolla yellow with brownish markings, 30-40 $\mathrm{mm}$ long, tube nearly $15 \mathrm{~mm}$ long, upper lip falcate. Stamens

2, type B, filaments 4-6 mm long. Upper connectives 10-15 mm long, lower connectives 
4-5 mm. Fertile anthers 4-5 mm long. Nutlets ovate-trigonous, $3.5 \times 2.0 \mathrm{~mm}$. Flowering period: July-October. Fruiting period: October-November.
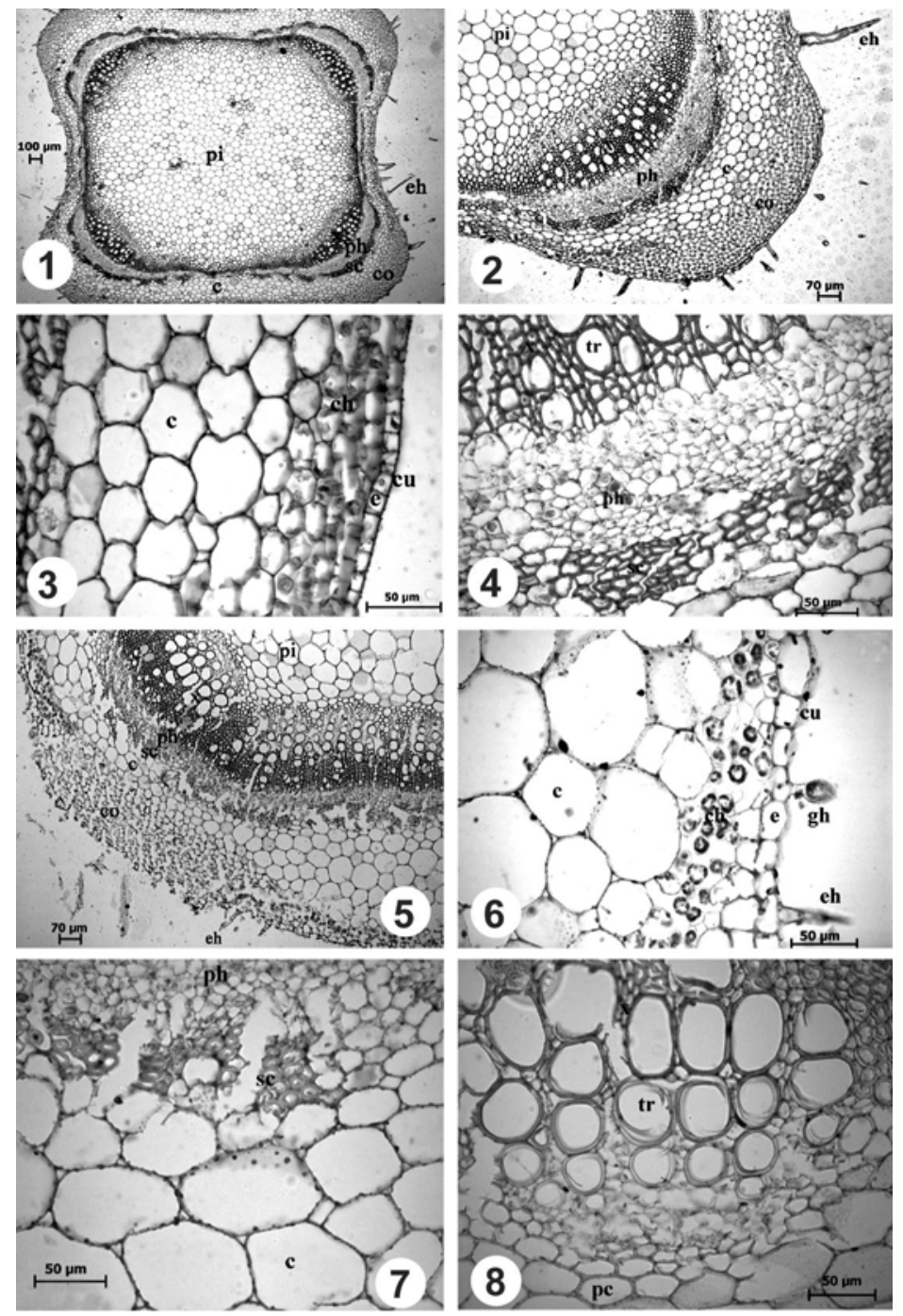

Figs 1-8. Transverse sections of the stem of Salvia glutinosa (Figs 1-4) and S. staminea (Figs 5-8). c, cortex; ch, chlorenchyma; co, collenchyma; cu, cuticle; e, epidermis; eh, eglandular hair; gh, glandular hair; pc, parenchyma cell; ph, phloem; pi, pith region; sc, sclerenchyma; tr, trachea; $x$, xylem.

S. staminea Montbret \& Aucher ex Bentham in Ann. Sci. Nat. ser. 2, 6: 41 (1836). Pobedimova in Not. Syst. (Leningrad) 21: 320-324 (1961).

Stems $20-70 \mathrm{~cm}$ tall, erect, rarely branched at the base. The stem indumentum eglandular pilose to villous. Leaves distributed over stem or rosette-forming, 2.5-15 × 1-6 $\mathrm{cm}$, linear-oblong to ovate, subentire to erose. Leaf indumentum subglabrous to shortly 
tomentose with sessile glands. Petiole $0.5-9.0 \mathrm{~cm}$ long. Inflorescence up to $40 \mathrm{~cm}$ long, paniculate, eglandular tomentose to villous sometimes with glandular pilose to villous. Verticillasters 2-6-(-8)-flowered and approximating above. Bracts 2-15 × 4-10 mm, broadly ovate. Pedicels 2-3 mm long. Calyx 6-8 $\mathrm{mm}$ long, up to $12 \mathrm{~mm}$ in fruit tubular-
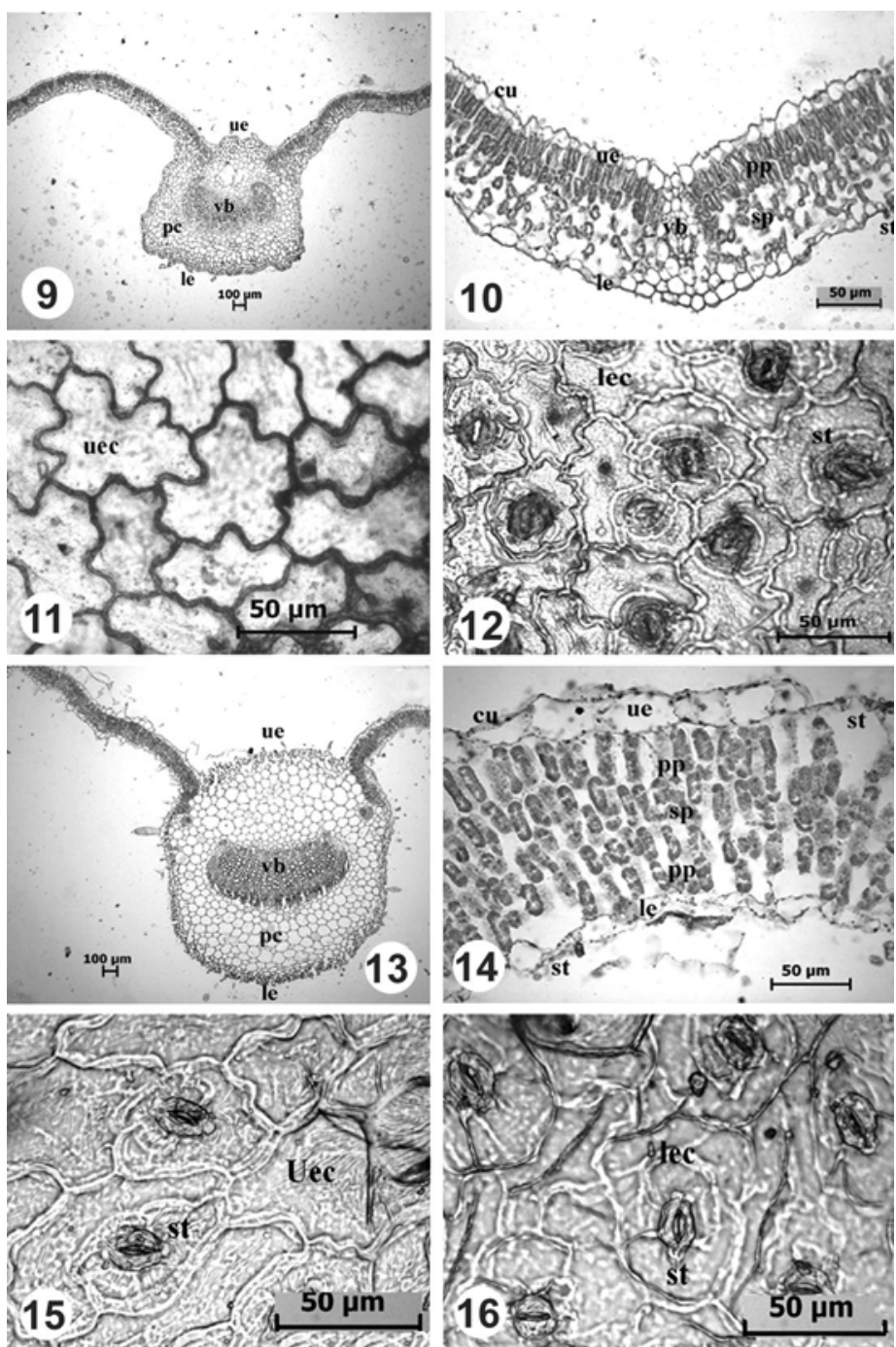

Figs 9-16. Transverse and surface sections of the leaf of Salvia glutinosa (Figs 9-12) and S. staminea (Figs 13-16). cu, cuticle; le, lower epidermis; lec, lower epidermal cell; pc, parenchyma cell; pp, palisade parenchyma; sp, spongy parenchyma; st, stomata; ue, upper epidermis; uec, upper epidermal cell; vb, vascular bundle.

campanulate, upper lip tridentate, equal to or shorter than lower. Calyx indumentum densely glandular or eglandular pilose with or without long flattened eglandular hairs. Corolla white to pale yellow, 12-16 $\mathrm{mm}$ long, tube almost $5 \mathrm{~mm}$ long, ventricose, 
squamulate, upper lip nearly straight and narrow. Stamens 2, type B, filaments 1-2 mm long. Upper connectives (5-)-9-15-(-18) mm, lower connectives 1-2 mm long. Fertile anthers 1.0-1.5 mm long. Nutlets rounded in transverse section and ovoid in outline, 2.0$2.8 \times 1.5-1.9 \mathrm{~mm}$. Hilum diameter $0.25-0.40 \mathrm{~mm}$. Nutlet surface glabrous, slightly tuberculate, mature nutlet colour light brown. Flowering period: May-August. Fruiting period: August-September.

The main morphological characters such as leaf shape and margin, calyx, corolla, filament and connective length, and nutlet size and shape are taxonomically important to identify these two species. Leaves of S. glutinosa are ovate-triangular and serrate while those of S. staminea are linear-oblong to ovate and subentire to erose. The length of calyces, corollas, filaments and connectives of S. glutinosa are taller than that of calyces, corollas, filaments and connectives of $S$. staminea. Nutlets of $S$. glutinosa are larger than that of S. staminea. Also, in S. glutinosa nutlets are ovate-trigonous, but in S. staminea nutlets are ovoid.

\section{Anatomical characteristics}

Table 1 compares detailed measurements of different cell and tissue types of stem, leaf and petiole of S. glutinosa and S. staminea.

Table 1. Comparative anatomy of the stem, leaf and petiole of Salvia glutinosa and S. staminea.

\begin{tabular}{lcccc}
\hline & \multicolumn{2}{c}{ S. glutinosa } & \multicolumn{2}{c}{ S. staminea } \\
\hline & Width $(\mu \mathrm{m})$ & Length $(\mu \mathrm{m})$ & Width $(\mu \mathrm{m})$ & Length $(\mu \mathrm{m})$ \\
\hline Stem & Min. - Max. & Min. - Max. & Min. - Max. & Min. - Max. \\
\cline { 2 - 5 } Cuticle & & & & \\
Epidermal cell & $2-3$ & & $3-5$ & \\
Cortex cell & $10-30$ & $8-15$ & $19-26$ & $11-17$ \\
Trachea cell & $36-75$ & $24-63$ & $38-113$ & $25-93$ \\
Pith cell & $17-34$ & $19-42$ & $20-51$ & $18-60$ \\
\hline Leaf & $30-103$ & $20-101$ & $46-139$ & $40-110$ \\
Cuticle & & & & \\
Upper Epidermal cell & $1-3$ & & $2-3$ & $17-50$ \\
Lower Epidermal cell & $20-40$ & $18-30$ & $33-56$ & $12-30$ \\
Palisade Parenchyma & $25-35$ & $20-32$ & $20-45$ & $21-35$ \\
Spongy Parenchyma & $9-14$ & $27-41$ & $7-11$ & $10-20$ \\
\hline Petiole & $19-29$ & $16-24$ & $9-17$ & $16-20$ \\
Abaxial Epidermal cell & $15-35$ & $12-17$ & $17-25$ & $17-23$ \\
Adaxial Epidermal cell & $12-34$ & $12-18$ & $20-30$ & $50-150$ \\
Cortex cell & $55-107$ & $31-93$ & $40-156$ & $18-38$ \\
Trachea cell & $16-34$ & $19-55$ & $16-37$ & \\
\hline & & & & \\
\hline
\end{tabular}


Stem anatomy: Transverse sections taken from the stem of S. glutinosa revealed (Fig. 1) that the epidermis is covered by a thin and smooth cuticle with glandular $(30-150 \mu \mathrm{m})$ or eglandular $(50-500 \mu \mathrm{m})$ hairs. The epidermis consists of uniseriate rectangular or squarish cells. Multilayered collenchyma cells $(40-150 \mu \mathrm{m})$ are located at the corners and between the corners (Fig. 2). Underneath the epidermis, there are 1-3-layered chlorenchyma cells $(35-50 \mu \mathrm{m})($ Fig. 3). The cortex $(50-200 \mu \mathrm{m})$ comprises of 3-6 layers of squashed oval or orbicular parenchymatous cells. The phloem, with sclerenchymatic fibers, measures 30-100 $\mu \mathrm{m}$ (Fig. 4). Cambium is not distinguishable. Size of the xylem is $50-260 \mu \mathrm{m}$ and it immediately bulges at ridges. The pith comprises of large hexagonal, polygonal or circular parenchymatic cells.

Transverse sections taken from the stem of S. staminea (Fig. 5) showed that the epidermis is covered by a thin and undulate cuticle with glandular or eglandular hairs. The epidermis is composed of uniseriate oval or rectangular cells. Underneath the epidermis, multilayered collenchyma cells $(80-160 \mu \mathrm{m})$ are located at the corners and between the corners. There are 2-4-layered chlorenchyma cells $(20-40 \mu \mathrm{m})$ (Fig. 6). The cortex $(130-350 \mu \mathrm{m})$ consists of 3-6 layers of oval or orbicular parenchymatous cells. The phloem $(30-50 \mu \mathrm{m})$ is surrounded by sclerenchymatic fibers (Fig. 7). Cambium is not clearly distinguishable. The xylem $(70-290 \mu \mathrm{m})$ considerably bulges at ridges. The pith is large and consists of hexagonal or orbicular parenchymatic cells (Fig. 8).

The stems of the family Labiatae (Lamiaceae) species are quadrangular and include well-developed collenchymatous cells at the corners (Metcalfe and Chalk, 1965). Moreover, it was also reported that scleranchymatic fibers surround the vascular tissue. This report is congruent with our results observing same anatomical characteristics in the stems of S. glutinosa and S. staminea. Our results also detected thicker, undulated cuticle in S. staminea, which prefers drier habitats, opposed to S. glutinosa. The cortex layer of S. staminea is also larger than that of S. glutinosa.

Leaf anatomy: Transverse sections of the lamina and surface preparations of both epidermis of S. glutinosa (Fig. 9) showed that the upper and lower epidermis that are covered with sparsely simple hairs consisting of uniseriate oval or rectangular cells with thin and undulate cuticles. The upper epidermis cells are nearly equal to the lower. Mesophyll region (140-165 $\mu \mathrm{m})$ consists of 2 or 3 layers of elongated palisade cells and 3 or 4 layers of nearly isodiametric spongy parenchymatic cells with large intercellular cavities (Fig. 10). The leaf is bifacial and hypostomatic. Stomata on the lower epidermis are of the diacytic type. Their length varies from 22-28 $\mu \mathrm{m}$ while their width ranges from 15-17 $\mu \mathrm{m}$ (Figs 11-12). In the midrib region, deeply crescentiform or U-shaped vascular bundles are surrounded by parenchymatic cells. There is a single large vascular bundle in the center.

Transverse sections of the lamina and surface preparations of upper and lower epidermis of S. staminea revealed (Fig. 13) that both epidermis are covered with densely 
eglandular hairs consisting of uniseriate, rectangular or oval cells with thin and undulate cuticles. The upper epidermal cells are larger than the lower. Mesophyll region (100-130 $\mu \mathrm{m})$ comprises of 2-3-layered palisade cells above, 1-2-layered below and 1-2-layered spongy parenchyma cells (Fig. 14). The leaf is equifacial and amphistomatic, with diacytic type (Figs 15-16). Stomata on the lower surface show higher frequencies than those on the upper surface. On the adaxial surface, the length of stomata varies from 15$19 \mu \mathrm{m}$ while the width of stomata ranges from 15-17 $\mu \mathrm{m}$. On the abaxial surface, the length of stomata varies from 17-19 $\mu$ m, whereas the width of stomata ranges from 15-17 $\mu \mathrm{m}$. In the midrib region, shallow crescentiform vascular bundles are surrounded by parenchymatic cells. There are a single large vascular bundle in the center and one small bundle on each side.
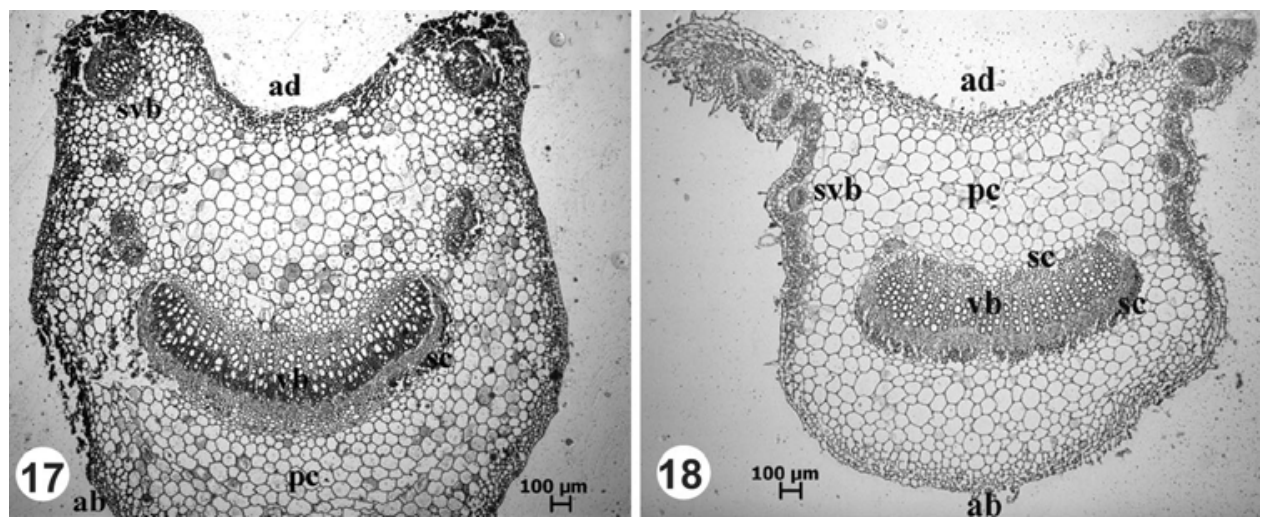

Figs 17-18. Transverse sections of the petiole of Salvia glutinosa (Fig. 17) and S. staminea (Fig.18). ab, abaxial epidermis; ad, adaxial epidermis; pc, parenchyma cell; sc, sclerenchyma; svb, subsidiary vascular bundle; vb, vascular bundle.

Mesophyll in Salvia species is entirely parenchymatic and the midrib is surrounded by collenchymatous cells (Metcalfe and Chalk, 1965). The leaves of S. indica (Kahraman et al., 2009a) are bifacial and amphistomatic, however those of S. halophila (Kaya et al., 2007) are monofacial and amphistomatic. According to the mesophyll structure, the leaves of S. glutinosa are bifacial and hypostomatic while those of S. staminea are equifacial and amphistomatic. Moreover, the vascular bundle structure of S. glutinosa is a deeply crescentiform or U-shaped, but that of S. staminea is shallow crescentiform. Salvia glutinosa has only single large bundle in the center, whereas $S$. staminea has a single large vascular bundle in the center and 2 small bundles on the sides. Salvia indica (Kahraman et al., 2009a) has one large and lobed vascular bundle in the centre, however S. halophila (Kaya et al., 2007) has two large bundles. Moreover, stomata in S. glutinosa are larger than S. staminea. To sum up, the distribution of palisade and spongy parenchyma cells, the presence of stomata on the upper surface, shape and number of the 
vascular bundle structure, and size of stomata are taxonomically significant characters in separating the species.

Petiole anatomy: Transverse sections taken from the petiole of S. glutinosa showed the following elements (Fig. 17). The epidermal cells of both surfaces are oval and rectangular. Adaxial and abaxial epidermis cells are nearly equal in size. One to three layers of collenchyma cells are located under the epidermis. The vascular bundle surrounded by parenchymatic cells appears as a shallow arc. A large single vascular bundle is located in the middle, as well as, there are 3 or 4 small subsidiary vascular bundles in each wing. A few sclerenchyma fibers are only observed on the phloem.

Transverse sections taken from the petiole of S. staminea showed the following elements (Fig. 18). The epidermal cells of both surfaces are squarish and nearly rectangular. The adaxial epidermal cells are slightly larger than the abaxial epidermal cells. There are 2 or 3 layers of collenchyma cells under the epidermis. A broad single vascular bundle is located in the middle, as well as, there are two or three small subsidiary vascular bundles in one petiolar wing and two small bundles in the other wing. The sclerenchyma tissue is well-developed outside of the phloem and xylem.

The structure of the vascular bundles in the petiole structure of the species of Labiatae could be used as a distinctive character (Metcalfe and Chalk, 1965). In the petiole of S. glutinosa, there is one large bundle in the center and there are 3 or 4 small subsidiary vascular bundles in each petiolar wings. In S. staminea, although there is a large single vascular bundle in the center, but there are 2 or 3 small subsidiary vascular bundles in one petiolar wing and two small bundles in the other wing. Kaya et al. (2007) investigated $S$. halophila found 6 broad vascular bundles in its middle of the petiole and 6 small bundles on its wings. Ozdemir and Altan (2005) observed in S. huberi a single large vascular bundle in the center of the petiole and 5 small lateral bundles, 2 of which are located in one petiolar wing and 3 in the other. While in S. glutinosa only phloem is surrounded by sclerenchyma fibers, both xylem and phloem in S. staminea are surrounded by sclerenchyma fibers. Thus, number of vascular bundles and the presence/absence of sclerenchymatous tissue in the petiole may serve as taxonomically diagnostic characters.

\section{Pollen characteristics}

Table 2 compares detailed measurements of different palynological features of $S$. glutinosa and $S$. staminea. The pollen grains of both the species are suboblate to prolatespheroidal (Figs 19, $20 \& 23,24$ ), while the exine sculpturing is bireticulate-perforate in both (Figs 21, $22 \& 25,26$ ). In S. glutinosa, lumina of the primary reticulum is extendedangular and lumina number of the secondary reticulum is less than 10; on the other hand, lumina of the primary reticulum is extended in S. staminea and lumina number of the secondary reticulum is more than 10 . 
Table 2. Comparative pollen morphology of Salvia glutinosa and $S$. staminea showing mean value \pm standard deviation, and the range in parenthesis. All measurements are in $\mu \mathrm{m}$ except $\mathrm{P} / \mathrm{E}$.

\begin{tabular}{lccccccc}
\hline Species & $\begin{array}{c}\text { Polar axis } \\
(\mathrm{P})\end{array}$ & $\begin{array}{c}\text { Equatorial } \\
\text { axis (E) }\end{array}$ & $\mathrm{P} / \mathrm{E}$ & Colpus length & $\begin{array}{c}\text { Colpus } \\
\text { width }\end{array}$ & $\begin{array}{c}\text { Exine } \\
\text { thickness }\end{array}$ & $\begin{array}{c}\text { Intine } \\
\text { thickness }\end{array}$ \\
\hline S. glutinosa & $51.8 \pm 4.4$ & $53.7 \pm 4.0$ & $0.8-1.1$ & $47.1 \pm 4.1$ & $3.5 \pm 1.1$ & $1.0 \pm 0.2$ & $0.5 \pm 0.1$ \\
& $(45.0-59.3)$ & $(48.2-59.9)$ & & $(40.0-52.6)$ & $(2.5-6.0)$ & $(0.9-1.3)$ & $(0.4-0.7)$ \\
S. staminea & $39.1 \pm 5.3$ & $44.1 \pm 3.7$ & $0.8-1.1$ & $33.5 \pm 5.0$ & $7.5 \pm 1.3$ & $1.2 \pm 0.1$ & $0.5 \pm 0.1$ \\
& $(32.5-48.8)$ & $(37.9-50.8)$ & & $(27.7-42.8)$ & $(5.7-9.4)$ & $(1.0-1.3)$ & $(0.5-0.7)$ \\
\hline
\end{tabular}

Pollen features of the family Labiatae have been reported to have considerable taxonomic importance (Erdtman, 1945). Cantino et al. (1992) revised the classification of all genera in Labiatae, and placed it within the subfamily Nepetoideae because the genus Salvia has hexacolpate pollen. Like S. glutinosa and S. staminea, suboblate to prolatespheroidal pollens are also found in S. indica (Kahraman et al., 2009a). Although the exine sculpturing of S. glutinosa, S. staminea (in the present study) and S. indica (Kahraman et al., 2009a) is bireticulate-perforate, in S. anatolica Hamzaoğlu \& A. Duran it is euryreticulate, and in S. bracteata Banks \& Sol. suprareticulate (Hamzaoglu et al., 2005). Nonetheless, differences in the size of the pollens, in the shape of primary lumina and in number of lumina of secondary reticulum are useful traits in distinguishing $S$. glutinosa and $S$. staminea.
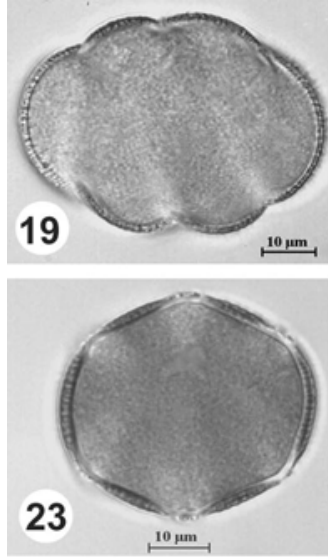
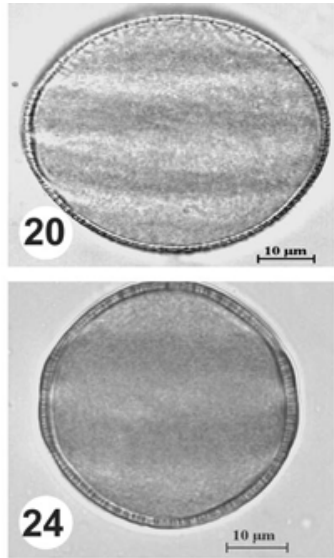
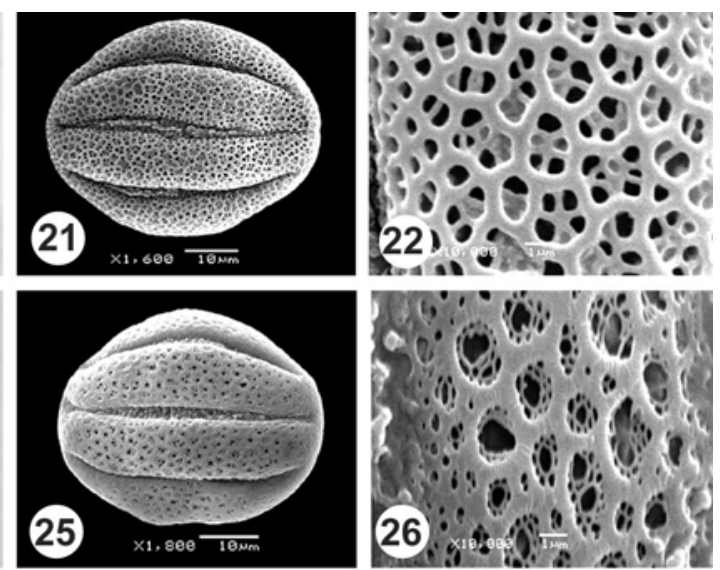

Figs 19-26. Light microscopy and scanning electron microscopy micrographs of pollen grains of Salvia glutinosa (Figs 19-22) and S. staminea (Figs 23-26). 19, 23. Polar view; 20, 21 \& 24, 25. Equatorial view; 22, 26. Exine ornamentation.

Salvia glutinosa and S. staminea have some significant differences in terms of not only morphological features but also anatomical and palynological characteristics which are useful to separate them. 


\section{Acknowledgements}

The authors wish to thank Technical Research Council of Turkey for their financial assistance (TUBİTAK-TBAG-104 T 450).

\section{References}

Bentham, G. 1833. Labiatarum genera et species. J. Ridgway \& Sons, London, pp. 1-783.

Boisseir, E.P. 1875. Flora Orientalis. Composees 3: 151-883.

Cantino, P.D., Harley, R.M. and Wagstaff, S.J. 1992. Genera of Labiatae: Status classification. In: Harley, R.M. and Reynolds, T. (eds), Advanced in Labiatae science. Royal Bot. Gardens, Kew, pp. 511-512.

Erdtman, G. 1945. Pollen morphology and plant taxonomy IV. Labiatae, Verbenaceae and Avicenniaceae. Svenk Bot. Tidskr. 39: 279-285.

Hamzaoglu, E., Duran, A. and Pinar, N.M. 2005. Salvia anatolica (Lamiaceae), a new species from East Anatolia, Turkey. Ann. Bot. Fenn. 42: 215-220.

Hedge, I.C. 1982. Salvia L. In: Davis, P.H. (ed), Flora of Turkey and the East Aegean Islands. Vol. 7. Edinburgh Univ. Press, Edinburgh, pp. 400-461.

Kahraman, A., Celep, F. and Dogan, M. 2009a. Morphology, anatomy and palynology of Salvia indica (Labiatae). World App. Sci. J. 6(2): 289-296.

Kahraman, A., Celep, F. and Dogan, M. 2009b. Morphology, anatomy, palynology and nutlet micromorphology of Salvia macrochlamys (Labiatae) in Turkey. Biologia (in press).

Kaya, A., Goger, F. and Baser, H.C. 2007. Morphological, anatomical and palynological characteristics of Salvia halophila endemic to Turkey. Nordic Journal of Botany 25: 351-358.

Metcalfe, C.R. and Chalk, L. 1965. Anatomy of the Dicotyledons. Vol. 2. Clarendon Press, Oxford, pp. $725-$ 1500.

Ozdemir, C. and Altan, Y. 2005. Morphological and anatomical characteristics of endemic Salvia huberi Hedge in Turkey. Bangladesh J. Bot. 34(2): 95-100.

Punt, W., Hoen, P.P., Blackmore, S., Nilsson, S. and Le Thomas, A. 2007. Glossary of Pollen and spore terminology. Review of Palaeobotany and Palynology 143: 1-81.

Walker, J.B. and Sytsma, K.J. 2007. Staminal evolution in the genus Salvia (Lamiaceae): Molecular phylogenetic evidence for multiple origins of the staminal lever. Annals of Botany 100(2): 375-391.

Wodehouse, R.R. 1935. Pollen Grains. McGraw-Hill, New York. pp. 1-574.

(Manuscript received on 11 January 2009; revised on 8 April 2009) 